\title{
カメラ内蔵ボールによるボール視点映像の生成
}

\section{Dynamic View Synthesis from Camera in Spinning Ball}

\author{
堀田高 大 $^{\dagger 1}$,
}

木谷クリス 真実 ${ }^{\dagger 2}$,

佐々木 秀貴 ${ }^{\dagger}$,

小 池 英 樹 ${ }^{\dagger 4}$

Kodai Horita ${ }^{\dagger 1}$, Kris M. Kitani ${ }^{\dagger 2}$, Hideki Sasaki ${ }^{\dagger 3}$ and Hideki Koike ${ }^{\dagger 4}$

\begin{abstract}
We placed a small wireless camera inside an American football to capture the ball's view during flight to augment the spectator's experience when watching American football. To this end, we propose a robust video synthesis algorithm that leverages the unique constraints of fast spinning cameras to obtain a stable bird's-eye-view video clip. Our algorithm uses coarse-to-fine image homography computation to progressively register images. We then optimized the energy function defined over pixel-wise color similarity and distance to image borders to find optimal image seams to create panoramic composite images. Our results show that we can generate realistic videos from a camera spinning at speeds of up to 600 RPM.
\end{abstract}

キーワード：デジタルスポーツ，ボールカメラ，イメージスティッチング

\section{1. まえがき}

古来からスポーツは人々に感動と興奮を与える重要なエ ンターテイメントである。テレビの発明とともに始まった スポーツ中継は，会場に来ることのできない遠隔地の人々 に対して，こうした感動と興奮を伝えることを可能とした. こうしたスポーツ中継は一般的には競技場周囲に設置され た複数台のパン・チルト・ズームカメラや，台車にのせられ た移動カメラ, カメラマンの手持ちカメラ, 飛行船等での 上空カメラを用いて臨場感を伝えようと努力してきた。最 近では，球技場上空にワイヤーで釣られた移動カメラやク レーンカメラを用いて，これまでにはない映像の提供を行 なっている。

こうした様々な試みにもかかわらず，これまで競技場内

2013 年 8 月 14 日受付， 2014 年 3 月 1 日再受付， 2014 年 9 月 3 日採録

$\dagger 1$ 電気通信大学 大学院情報システム学研究科

( ₹ 182-8585 東京都調布市調布ヶ丘 1-5-1)

$\dagger 2$ Robotics Institute, Carnegie Mellon University

(500 Forbes Ave. Pittsburgh, PA, USA)

$\dagger 3$ 株式会社ニコンコアテクノロジーセンター

( 140-8601 東京都品川区西大井 1-6-3)

$\uparrow 4$ 東京工業大学 大学院情報理工学研究科

( ₹ 152-8552 東京都目黒区大岡山 2-12-1)

$\dagger 1$ Graduate School of Information Systems, University of ElectroCommunications

(1-5-1, Chofugaoka, Chofu, Tokyo 182-8585, Japan)

$\dagger 2$ Robotics Institute, Carnegie Mellon University (500 Forbes Ave. Pittsburgh, PA, USA)

$\dagger 3$ Core Technology Center, NIKON Corporation (1-6-3, Nishiohi, Shinagawa-ku, Tokyo 140-8601, Japan)

$\dagger 4$ Graduate School of Information Science and Engineering, Tokyo Institute of Technology

(2-12-1, Oookayama, Meguro-ku, Tokyo 152-8552, Japan)
部にカメラを設置し，競技場内部からの映像の配信は困難 であった。最大の理由は，競技場内にカメラを設置すると 競技の邪魔となると同時に，選手の安全が懸念されるから である。これに対し，金出ら ${ }^{3)}$ は競技場周辺に設置された互 いに同期する複数台のパン・チルト・ズームカメラ映像か ら，隣り合うカメラ間の中間画像生成による画像補完によ り実際にはカメラのないアングルからの映像の提供を行っ た。しかし，カメラが競技場外部にあるため，競技場内部 からの視点の映像提供には限界がある.

一方, 高性能力メラの小型化, 低価格化が進んでいる.こ の結果, 小型カメラを例えば選手自身のヘルメットや，サー フボード等の器具に装着し, 従来の固定カメラでは不可能 だった映像の撮影が可能となり，動画投稿サイトには多く の動画が投稿されている。

こうした背景のもと，本研究は球技に着目し，ボールに 小型カメラを内蔵することで，ボール視点の映像を提供す ることを試みた (図 1)。この結果，例えばフットボールで は，ハドル時などボールが静止している時のボール視点映 像はもちろん，パス時の空中からの映像など，従来は不可能 であった映像配信が可能となる。こうしたカメラ内蔵ボー ルは，ボールの重量とバランスさえ基準を満たせば公式競 技での使用も充分可能であると考える.

ここで問題となるのは，一般に飛行中のボールは回転，し かも高速回転していることである，具体的には，本論文が 対象とするアメリカンフットボールの場合，長軸周りに約 600RPM で回転している。したがって，カメラからのオリ ジナル映像をそのまま提供しても，視聴者には意味のある ものとならない。また，撮影された各フレームは高速回転 
のためのモーションブラーやローリングシャッタのため歪 んでいる。そこで本研究の目的は, 高速回転する映像から, 必要な画像フレームのみを抽出し, 各フレーム間をスムー ズにつなぎ合わせることで，あたかもボールが回転してい ないかのような擬似直進映像を合成することである. 図 2 に回転するボールから一方向の画像フレームのみを抽出す る概念図を示す。

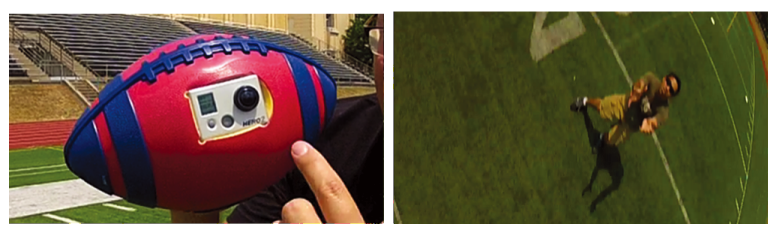

図 1 試作したカメラ内蔵ボール (左) とカメラからの映像 (右). A prototyped american football and the ball's POV

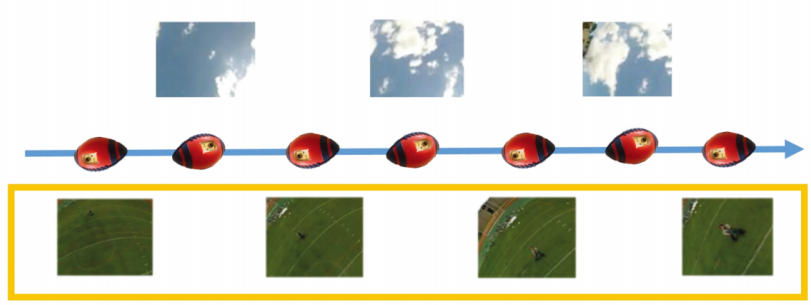

図 2 回転しているボールカメラから地面を向いている画像を 抽出するイメージ図

Illustration of how to select the images looking down the filed.

\section{2. 関 連 研 究}

ボールあるいはボール型のものにカメラを内蔵するとい う考え方はこれまでにも幾つか見られる。

Mori ら ${ }^{7)}$ は Point Grey 社製の多眼カメラ Ladybug を 用い, ボールやバットなど異なる視点からの映像を提供す る MotionSPHEREを提案した。しかし, Ladybugをそ のまま使用しているため，独立したボールとして使用する ことは不可能で，また，高速に移動・回転する場合の映像処 理は考慮されていない. Ozawa ら ${ }^{9)}$ は, 複数台のカメラを ボールに内蔵し，パノラマ映像を撮影するシステムを開発 した。このシステムの特徴は，パノラマ映像の継ぎ目に人 間がいる場合の不自然な接合を解決するために，パノラマ 合成に顔認識を組込んだ点にある。しかし，実際に高速に 移動・回転するカメラからの映像は扱っていない. Kuwa ら5)は, 単体のカメラを投げた時の映像からリボン型の広 範囲映像の合成を行った。しかし得られる映像はパノラマ 画像であり, 本研究のような擬似直進映像の合成は考慮し ていない.

本研究に最も近いものとして, Pfeil らのカメラ内蔵ボー ル, Throwable Panoramic Ball Camera ${ }^{10)}$ がある.この
ボールには 36 個の携帯電話用小型カメラと加速度センサ が内蔵され，ボールを投げ上げると，最高点に達した時に 36 個のカメラが同時に映像を撮影する。その後, 全画像を $\mathrm{USB}$ 経由で PC に取り込み，全周囲パノラマ映像を生成す る。ボール視点映像の提供という点での発想は本研究と似 ているが, Pheil らのボールは静止画のパノラマ撮影が目 的であり，動画には対応していない。また最大の相違点は, Pheil らのボールはボールの回転をまったく考慮していな いことである.よって, ボールが回転している場合に生じ る，モーションブラーやローリングシャッタ問題に対する 考慮がない.さらには, 本研究の主たる貢献である高速に 移動・回転する映像からの直進映像の合成は考えられてい ない.

本研究ではボール視点映像生成のためにパノラマ画像生 成技術で用いられる技術を改良した。一般的なパノラマ合 成では多くの場合ブレンディングによる重なり領域の画像 合成を行う。たとえば Levin $ら^{6)}$ や Uytendaele $ら^{8)}$ は合 成の際に画像の形状は変えずにブレンディングをすること で画像を合成している。このような画像合成は一般的であ り，カメラキャリブレーションが完全で，かつ被写体が遠 方である前提で用いられている。

これらのパノラマ合成技術との違いは，カメラが高速に 移動していることである。通常カメラが高速に動いている 場合，様々な問題が発生しきれいに画像を合成することが できない。そのため，これらの一般的なパノラマ合成手法 では，本研究のようにボール視点映像を生成できない。本 研究では, 高速に回転しているカメラからの画像でも合成 ができるような手法を開発している。

\section{3. ボール視点映像の生成}

本章ではボール視点映像の生成について説明していく. 本研究ではボール型カメラから撮影された映像を元にボー ル視点映像を生成していくが，まずカメラがほぼ同じ方向 を向いている画像だけを抽出する。その後，高速に回転し ている影響で発生する歪みを除去する。次に，カメラの向 きのずれを補正してから，よりダイナミックな映像にする ために仮想的な視野拡張を行う。この視野拡張ではパノラ マ画像生成の技術を改良したものを使用している。そして 視野拡張を終えたあとは，ボール視点映像を生成する際，よ り滑らかな映像を生成するために画像間のモーション補間 を同じく画像合成を用いて行っていき，ボール視点の映像 を生成していく.

\section{1 回転する映像からの単一視点画像の抽出}

高速に回転するカメラから単一方向の視点の映像を生成 する際, カメラの向きを推定する必要がある。本研究では 高速に回転するカメラの向きを推定する手法として, 映像の 各フレーム画像の全画素の輝度值平均を用いた。 各フレー 厶の輝度值平均の時間変化は図 4 で表される。ただし,こ れは屋外スタジアムの晴天時の場合であり，空が暗い場合 

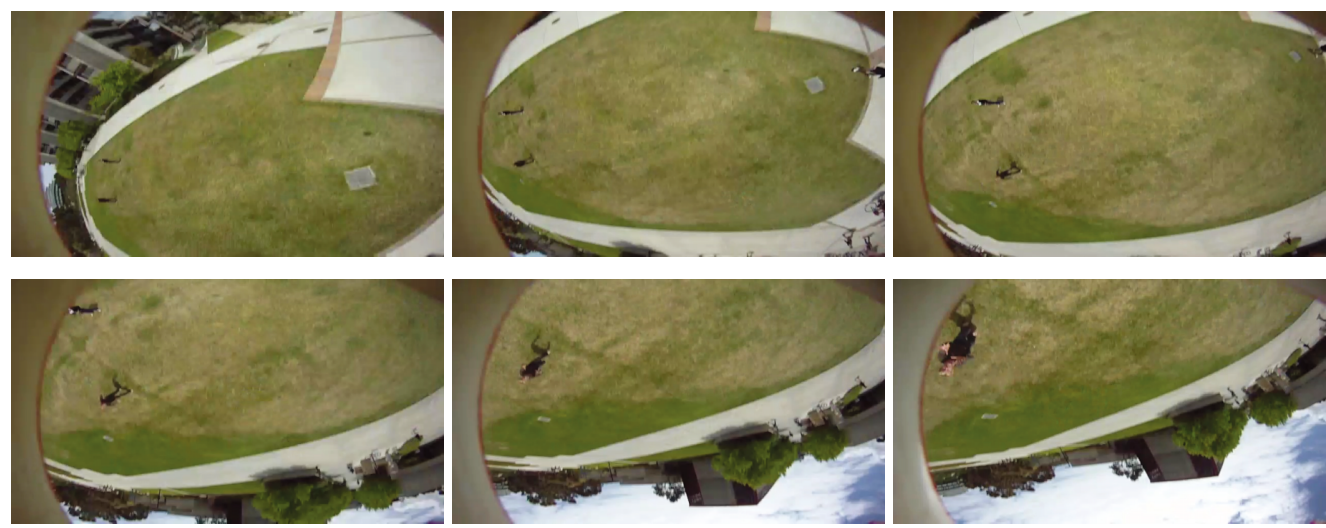

図 3 輝度值平均により抽出された画像群

Images selected by their mean image intensity.

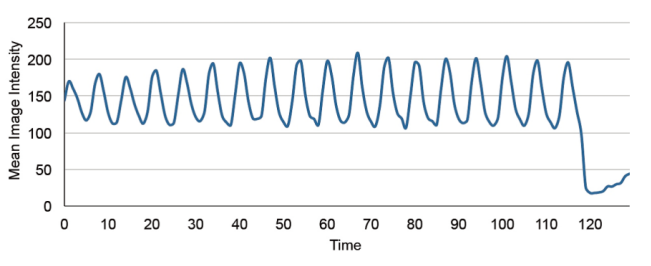

図 4 回転するボールから得られる画像の輝度值平均のグラフ Plot of image intensity over time.

や屋内の場合はこのようになるとは限らない.

この図 4 から輝度值平均は周期的になっていることがわ かる，ここで，次の二つの前提条件を定義する.

（1）ボールの回転軸は地面とほぼ水平である

（2）ボールは必ず空と地面を撮影しながら飛行していく この二つの前提条件は今回使用したアメリカンフットボー ルの回転軸が固定されているため成立する。この前提条件 を元に先ほどの輝度值平均のグラフを見ると, カメラが空 を向いているときはより明るいため輝度值平均は高い值を 示し，地面を向いているときは輝度值平均が低くなってい る。 そのため, 本研究では輝度值平均が低い画像を抽出す ることで，カメラが下方向を向いた画像を抽出することが できる。このとき抽出した画像シーケンス群が図 3 である.

図 3 より，カメラが地面を向いている画像を抽出できて いるのがわかる. しかし，この手法ではカメラの向きは完 全に同じわけではない，そのため，本研究ではこのカメラ の向きのズレを補うために仮想的な画像の視野拡張を行う.

\section{2 歪み補正}

今回用いたカメラは広角レンズを使用しており，得られ る画像には大きなレンズ歪みがある。また, 撮像素子はロー リングシャッタを使用する CMOS であるため, カメラを 高速に回転させながら撮像を行うと, ライン毎に露光タイ ミングが異なる事による画像の歪みが生じる。この二つの 歪みは, 後述すると抢り, 最初にレンズの歪みパラメー夕 を取得した後に，それを使ってレンズ歪みを補正した画像 を使って, 露光タイミングに係る画像歪みパラメータを取 得する。
（1）歪み補正のための変換式の導出

3 次元空間内の点の座標を $\tilde{\boldsymbol{X}}=[X, Y, Z]^{\top}$ とし, それに 対応する撮像面上の画像座標を $\boldsymbol{x}=[x, y, 1]^{\top}$ とする。 ンズの歪みが無い場合，これらの関係はカメラの内部行列 $K$ を用いて

$$
\boldsymbol{x}=K \tilde{\boldsymbol{X}}
$$

と表わせる。レンズの歪みがある場合，式 (1) は次のよう に書き直せる。

$$
\boldsymbol{x}=K \mathcal{D}(\tilde{\boldsymbol{X}})
$$

ここで，D はレンズ歪みの影響を表す関数である。レンズ 歪みのモデルとしては, 一般的な多項式展開による動径方向 歪みモデルを用いた ${ }^{11)}$ 。すなわち $\left[X^{\prime}, Y^{\prime}, 1\right]=\mathcal{D}(\tilde{\boldsymbol{X}})$ と した場合， $X^{\prime}, Y^{\prime}$ は歪みを表すパラメー夕 $k_{1}, k_{2}$ を用いて

$$
\begin{aligned}
& X^{\prime \prime}=X / Z, \quad Y^{\prime \prime}=Y / Z \\
& r=\sqrt{X^{\prime \prime 2}+Y^{\prime \prime 2}} \\
& a=1+k_{1} r^{2}+k_{2} r^{4} \\
& X^{\prime}=a X^{\prime \prime}, \quad Y^{\prime}=a Y^{\prime \prime}
\end{aligned}
$$

のように計算される。

カメラが回転している場合，ローリングシャッタによる ライン毎の露光タイミングのずれを考慮して式 (2) を書き 直すと, 次式のようになる。

$$
\boldsymbol{x}=K \mathcal{D}(R(\hat{\boldsymbol{n}} ; \alpha y) \tilde{\boldsymbol{X}})
$$

ここで，露光時間中のカメラの並進は充分小さいとし，そ の影響は無視できるものとした。また， $R(\hat{\boldsymbol{n}} ; \theta)$ は $\hat{\boldsymbol{n}}$ を回 転軸とする角度 $\theta$ の回転を表す回転行列であり， $\alpha$ は 1 ラ インを露光する時間あたりのカメラの回転角である.

3 次元空間内の点 $\tilde{\boldsymbol{X}}$ を撮像した場合の, 歪み補正前後の 画像座標 $\boldsymbol{x}_{d}=\left[x_{d}, y_{d}, 1\right]^{\top}, \boldsymbol{x}_{r}=\left[x_{r}, y_{r}, 1\right]^{\top}$ は, 式 $(1,3)$ よりそれぞれ

$$
\boldsymbol{x}_{d}=K \mathcal{D}\left(R\left(\hat{\boldsymbol{n}} ; \alpha y_{d}\right) \tilde{\boldsymbol{X}}\right)
$$




$$
\boldsymbol{x}_{r}=K \tilde{\boldsymbol{X}}
$$

である。この 2 式から $\tilde{\boldsymbol{X}}$ を消去する事により，画像の歪 み補正のための变換式

$$
\boldsymbol{x}_{r}=K R\left(\hat{\boldsymbol{n}} ;-\alpha y_{d}\right) \mathcal{D}^{-1}\left(K^{-1} \boldsymbol{x}_{d}\right)
$$

が得られる. カメラの内部行列 $K$ および歪み関数 $\mathcal{D}$ のパ ラメータ $k_{1}, k_{2}$ は, 事前のキャリブレーションにより得る 事ができる。したがって，カメラ回転のパラメータ $\hat{\boldsymbol{n}}, \alpha か ゙$ 分かれば，式 (4)の変換により画像の歪み補正を行える.

(2) カメラ回転の推定

カメラから得られる動画像の第 $n$ フレーム, 第 $n+1$ フ レーム間でオプティカルフローを計算し, 対応点を求める. 各フレームでの対応点の座標をそれぞれ $\boldsymbol{x}_{d}^{n}, \boldsymbol{x}_{d}^{n+1}$ とし, 式 (4)によりこれらの歪み補正を行った結果を $\boldsymbol{x}_{r}^{n}, \boldsymbol{x}_{r}^{n+1}$ とす る. 画像の高さを $h$ とした場合, フレーム間のカメラの回 転は $R(\hat{\boldsymbol{n}} ; \alpha h)$ である.フレーム間のカメラの並進量は無 視できるほど小さいとした場合, $\boldsymbol{x}_{r}^{n}, \boldsymbol{x}_{r}^{n+1}$ はよく知られて いるように

$$
\boldsymbol{x}_{r}^{n+1}=K R(\hat{\boldsymbol{n}} ; \alpha h) K^{-1} \boldsymbol{x}_{r}^{n}
$$

というホモグラフィで結ばれる21.Kは事前のキャリブレー ションにより既知であるため, 式 (5) で得られるホモグラ フィからカメラ回転のパラメータを求める事ができる.

式 (5) のホモグラフィの計算は歪み補正後の座標を用い るが，歪み補正のためにはカメラ回転のパラメータを子め 知っておく必要がある。そこで, 以下の手順によりカメラ 回転の推定を行った。

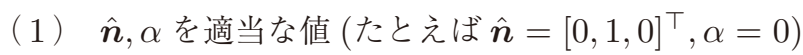
に初期化する。

（2）現在の $\hat{\boldsymbol{n}}, \alpha$ の值を用いて $\boldsymbol{x}_{d}^{n}, \boldsymbol{x}_{d}^{n+1}$ の歪み補正を 式 (4)により行う.

（3）式 (5)よりホモグラフィを求め，その計算により 得た $\hat{\boldsymbol{n}}, \alpha$ を新たな $\hat{\boldsymbol{n}}, \alpha$ とする。

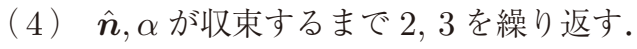

飛行中のボールの回転軸および回転速度は一定とみなせ る事に注意すると, カメラ回転のパラメータは動画を通し て同一の值を取る事が分かる。そこで，複数の隣接フレー ム間で回転パラメータの推定を行い, それらの平均1)を取 る事で，最終的な回転パラメー夕を得た。

得られた回転パラメー夕を用いて画像の歪み補正を行っ た結果が図 5 である。

\section{3 抽出画像の視野拡張}

視野拡張は抽出した画像の前後のフレームを用いること で行う。ボール型カメラは高速に回転しているため, 同じ 時間に撮影されてはいないが，連続する 3 枚の画像には重 なり領域が出現するため, 仮想的な画像の視野拡張を行う ことができる。この 3 枚の画像を合成した後，回転周期を 調整するためにこの合成画像同士 2 枚を同様に合成し，さ
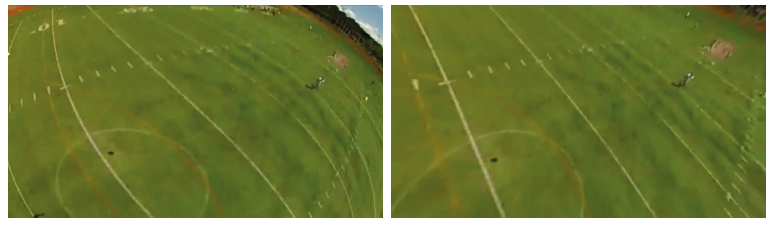

図 5 ローリングシャッタとレンズ歪み除去. 処理前(左) と 処理後 (右)

Result of rolling-shutter and lens distortion removal.

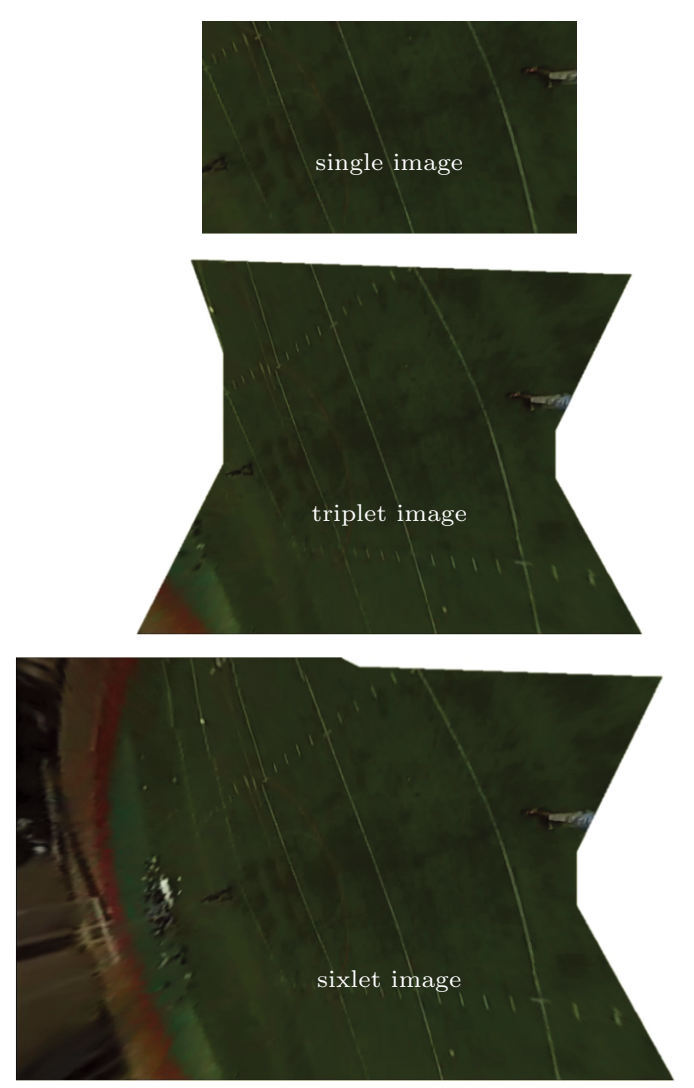

図 6 視野拡張. 上から 1 枚の画像, 3 枚の画像の合成画像. 6 枚の画像の合成画像.

View expansion. An original image (top), an expanded image with three images (middle), and an expanded image with six images (bottom).

らに視野を広げていく。この視野拡張の様子を図 6 に示す。

(1) Coarse-to-Fine Homography Estimation

合成画像を生成するために，変換される画像間のホモグ ラフィを計算する必要がある。しかし，アメリカンフット ボールのフィールドは似たパターンの色をしている事，ま た画像の歪みを完璧に取り除けるわけではないため，似た 特徴を持つ画像と歪みの影響で特徴点の抽出を行う際にミ スマッチを引き起こす可能性が高い (図 7). そこで本研究 では，回転する画像におけるロバストなホモグラフィ推定 を行っていく.

まず，並進移動 $T$ の動きを線形式を用いて推定する.

$$
\left[\begin{array}{l}
x^{\prime} \\
y^{\prime}
\end{array}\right]=A\left[\begin{array}{l}
x \\
y \\
1
\end{array}\right]
$$




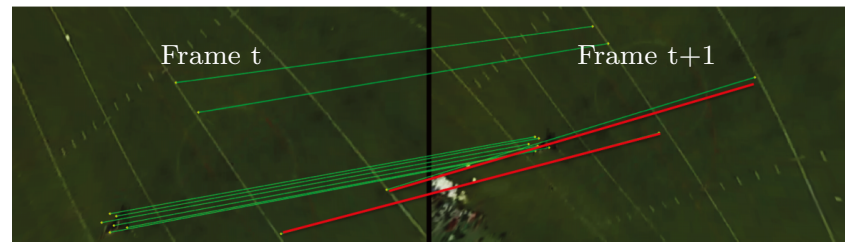

図 7 特徵点のミスマッチ例.

Bad point correspondences (marked in red) identified via a coarse-to-fine motion estimation
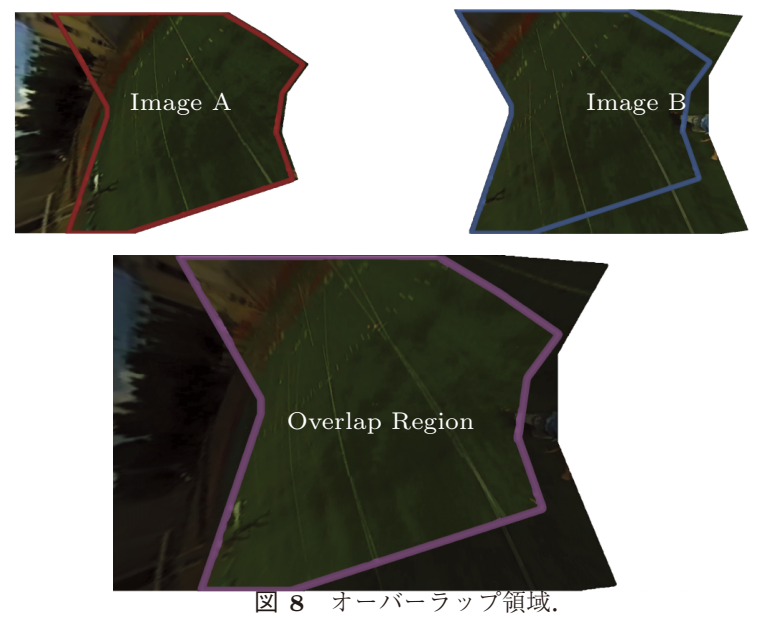

Overlap region from merging images.

$$
A=\left[\begin{array}{lll}
1 & 0 & t_{x} \\
0 & 1 & t_{y}
\end{array}\right]
$$

このとき, $x$ と $y$ は現在のフレーム画像における特徽点, $x^{\prime}$ と $y^{\prime}$ は次のフレーム画像の特徴点である.

$\left(t_{x}, t_{y}\right)$ は現在のフレームの特徵点 $(x, y)$ の平均と次のフ レームの特徵点 $\left(x^{\prime}, y^{\prime}\right)$ の平均との差分として求めること ができる。これは $\left(t_{x}, t_{y}\right)$ を最小二乗で推定した結果にな る。このモデルから明らかに大きく外れているものを除去 する。この明らかにミスマッチを起こしそうな特徵点を削 除したあと，残った特徴点を用いて，RANSACアルゴリ ズムを用いてホモグラフィ行列 $H$ を求めていく.

(2) Image Stitching with Graphcuts

視野拡張のために画像を合成する際, 画像同士の合成の 仕方について様々なノイズを考慮した方法にしなければな らない. 本研究では画像同士の重なり領域に打ける最適な カットラインを求めることで，合成を行っていく．図 8 は 実際の重なり領域の画像である。視野拡張における画像合 成のゴールとしてはこの重なり領域内での最適なカットラ インを求めることである.

単純なホモグラフィを用いた合成ではボール型カメラで 撮影された画像が固定されて㧍らず完壁な平面ではないた め, 画像にノイズが発生してしまう。また4) と9)がボー ル型カメラに拉ける画像合成の際，ひとつのカットライン しか求めることができなかったのに対し，本研究ではグラ フカットアルゴリズムを用いることにより, 複数のカット ラインを同時に求めていくボール型カメラに扔ける画像合
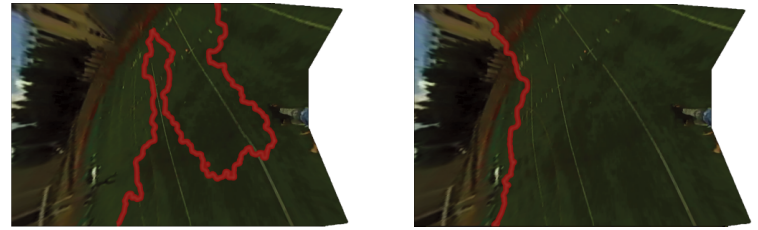

図 9 色差コストのみによるカットライン (左)，色差コストと 距離コストによるカットライン (右).

Optimal seam computed with the distance cost preserves spatial continuity.

成に拡張した。またこの時，エネルギーのコストとして画 像の重なり領域における色差と重なり領域となっている境 界からの距離をコストとして用いた。

二つの画像のピクセル $i$ と $j$ における色差コストは, 重 なっている画像の前景となるピクセル $\vec{f}(\cdot)$ と背景となるピ クセル $\vec{b}(\cdot)$ の色の差により求める.

$$
C_{\text {color }}(i, j)=\frac{1}{N}\left(\|\vec{f}(i)-\vec{b}(i)\|^{2}+\|\vec{f}(j)-\vec{b}(j)\|^{2}\right)
$$

$\|\vec{f}(\cdot)-\vec{b}(\cdot)\|^{2}$ は RGB 值のそれぞれの差の 2 乗の合計で, $N$ はコストを 0 から 1 の間に正規化する要素である.

色差コストが低い部分を選択しながら，カットラインを 決定し重なり領域を切り取ることもできる。しかし，視野 搪張に打ける目的はあくまでも，カメラのズレを修正する ために視野を補うことであり，中心となる抽出された画像 の大部分をカットしてしまうと, 次に行う画像間のモーショ ン補間で問題が起きてしまう。この影響を表したものが図 9 である。このように抽出された画像の半分ほどを切り取 り，拡張のための画像に置き換わっていることがわかる. そこで本研究では距離コストの導入を行った。距離コス卜 は拡張のための画像同士の重なり領域の境界から距離が遠 い重なり領域のピクセルがもつコストを高くするものであ る。境界線から遠くなるにつれてコストをあげていく，次 の式がその距離コストを設定するものである.

$$
C_{\text {dist }}(i)=\min _{\vec{b} \in B}\|\vec{b}-\vec{x}(i)\|_{L 2}^{-1}
$$

$b$ は $i$ から一番近い境界線上の点の座標を表し， $B$ は境界 線上のすべての点を表している。そして,$x(i)$ は $i$ の座標 を表す。このコストによりカットラインは重なり領域の境 界線の近くを通ることが可能になる。

最適なカットラインはこれら二つのコストを用いて以下 のエネルギー関数を最小化する。

$$
C_{\text {total }}=\alpha \sum_{i} C_{\text {dist }}(i)+\sum_{i} \sum_{j \in n(i)} C_{\text {color }}(i, j)(10)
$$

ピクセル単位の距離コストの重み付け $\alpha$ は経験的に設定 して，平滑化項である色コストは各ピクセルに隣接してい る 4 近傍ピクセル $n(i)$ に対して計算する. 


\section{4 Video Motion Interpolation}

バーチャルなカメラパスを生成するために，視野拡張画 像間で計算されたホモグラフィを用いた画像の補間を行う 必要がある。本研究はホモグラフィから各ピクセルのマッ ピング情報を次の式により求める.

$$
\begin{aligned}
z & =h_{20} \times x+h_{21} \times y+h_{22} \\
x^{\prime} & =\left(h_{00} \times x+h_{01} \times y+h_{02}\right) / z \\
y^{\prime} & =\left(h_{10} \times x+h_{11} \times y+h_{12}\right) / z
\end{aligned}
$$

$z$ は正規化のための要素, $x^{\prime}$ と $y^{\prime}$ は $x$ と $y$ の各ピクセルが 変換される先のピクセル, $h_{i j}$ ホモグラフィ行列の要素で ある。

$$
H=\left[\begin{array}{lll}
h_{00} & h_{01} & h_{02} \\
h_{10} & h_{11} & h_{12} \\
h_{20} & h_{21} & h_{22}
\end{array}\right]
$$

マッピング情報 $M_{f}(x, y)$ は現在のフレーム $t$ の画像が 次のフレーム $t+1$ へ変換される際の情報が格納されてい る。本研究ではこのマッピング情報を用いてモーション補 間を行っていく.マッピング情報は他に画像 $t$ が移動しな いときの情報である固有マッピング $M_{I}(x, y)$ と $t+1$ の画 像が $t$ の画像へ戻るときのマッピング情報 $M_{b}$ があり，こ れら三つの情報を用いて線形式を作成する。

$$
\begin{aligned}
& F(x, y)=(1-\alpha) M_{I}(x, y)+\alpha M_{f}(x, y) \\
& B(x, y)=(\alpha) M_{I}(x, y)+(1-\alpha) M_{b}(x, y)
\end{aligned}
$$

ここで新しいマッピング情報 $F$ は重み $\alpha(0 \leqq \alpha \leqq 1)$ と フレーム $t$ から $t+1$ へのマッピング情報 $M_{f}(x, y)$ と固有 マッピング情報により作成される。同様に， $B$ も重み $\alpha$ と $t+1$ から $t$ へと変換されるマッピング情報 $M_{b}(x, y)$ を用 いて表すことができる。これは例えば，重み $\alpha=0$ の時， マッピング情報 $F$ は固有のマッピング情報 $M_{I}(x, y)$ と同 じになる。言い換えると，マッピング情報 $F$ を用いて画像 $t$ を変換しても，画像 $t$ はそのままである，さらにマッピ ング情報 $B$ は $M_{b}(x, y)$ と同じになり，この情報を用いて 画像 $t+1$ は画像 $t$ に変換される.そしてこの二つの変換 された画像を合成する。その後は $\alpha$ の值を除々に増やしな がら, 画像を少しずつ変換, 二枚の画像を合成というよう に視野拡張された画像間のフレームを補間していく。しか し，このままではボールの回転軸に影響され生成される映 像は非常に見づらいものとなってしまう。そこで，本研究 ではより滑らかな映像を生成するために, 中間画像を生成 し線形モーション補間を行っていく.

この中間画像による線形モーション補間とは，各画像を 先ほどの線形補間式の重み $\alpha=0.5$ で変換し作成した中間 画像同士をもちいるものである。各視野拡張画像を初めに 中間画像に変換する。そして，この中間画像同士のホモグ ラフィを計算し，同じように中間画像どうしで線形補間式 を作成する。この線形補間式を用いることでカメラの回転
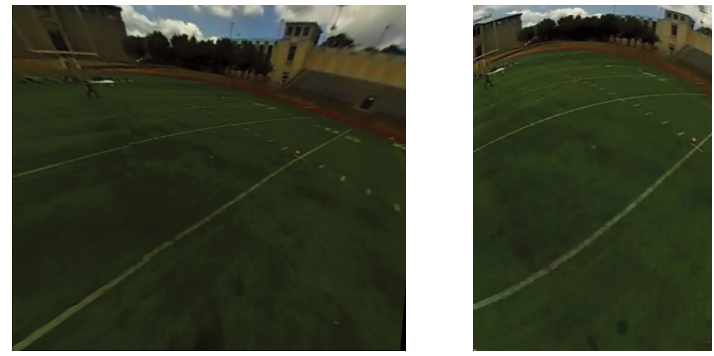

図 11 Frame 0 に扔けるオリジナル映像との比較. (左) 視野 拡張画像. (右) オリジナル画像.

Comparison between a synthesized image and an original image at frame 0

軸により，映像をより安定にし滑らかなものを作成するこ とを可能にする。

\section{4. 議 論}

図 10 は本研究で作成したボール視点映像のいくつかの 結果である。図 11 はフレーム 0 に㧍ける合成画像とオリ ジナル画像の比較である。これを見てわかるように歪みは ほほ除去できており，画像合成も違和感なく行えており，視 野拡張画像の生成ができている。ここで実際に作成した映 像は筆者の Web サイトで見ることが可能になっている。

これにより，回転するカメラから単一視点の映像を生成 することができることを示した。しかし幾つか問題も残っ ている，歪み補正においては，歪みの大部分を取り除くこ とはできたが，まだ完全に歪みを補正できているとはいえ ない(ラインが少し湾曲している部分もある).さらにモー ションブラーもまだ残っている，歪み補正に関しては，キャ リブレーションが不充分だからと考えられる。モーション ブラーに関してはより高速なカメラや，ブラー除去などの 超解像技術を用いて対処できると考えられる.

現在のフレームワークとして，ボールの回転軸はアメリ カンフットボールの綺麗な回転により保障されており，こ れを前提条件として映像の生成を行った。しかし，他のス ポーツに対応させることを考えたとき，回転軸が固定され ているとは限らないため，現状他のスポーツでの映像生成 はできない。 今後は，ボールの回転軸をセンサの追加やカ メラの個数を増やすことにより推測し，同じようにボール視 点の映像を生成する技術を開発していくことを考えている.

\section{5. むす び}

本論文ではロバストな新しいボール視点の映像生成手法 を提案し，実装を行った。本システムで作成した映像では， ボールからフィールドを見渡しているかのような体験をす ることができ，球技競技における新しい観戦技術を提供で きることを示した。今回はアメリカンフットボールという 限られたものなっているが，今後他の球技スポーツでの実 装を行っていく予定である。この本研究におけるプロト夕 イプは，今後スポーツ観戦に新しいスタイルをもたらすと 


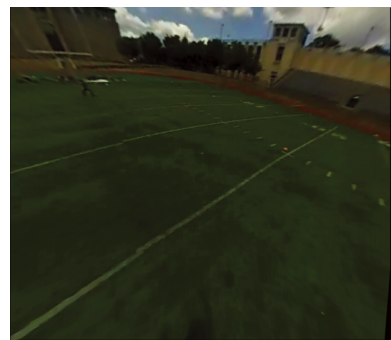

frame $=0$

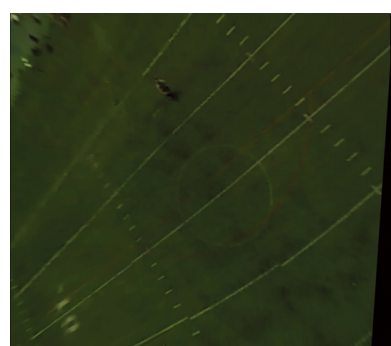

frame $=10$

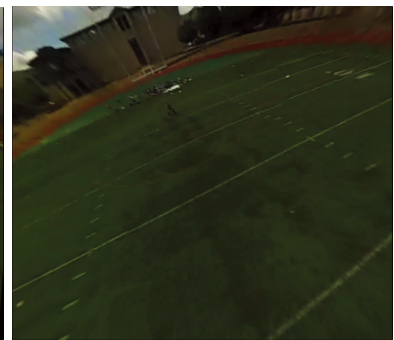

frame $=2$

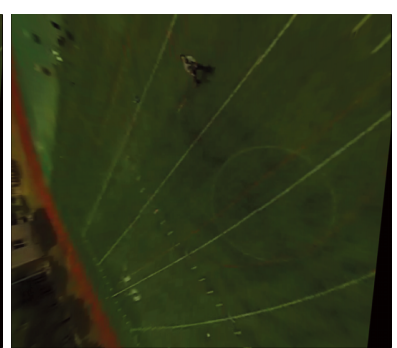

frame $=12$

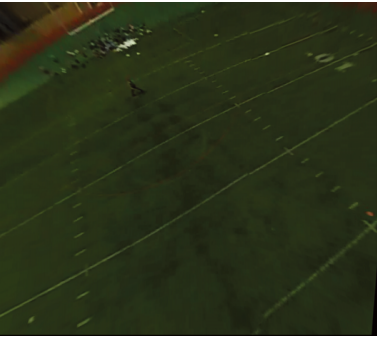

frame $=4$

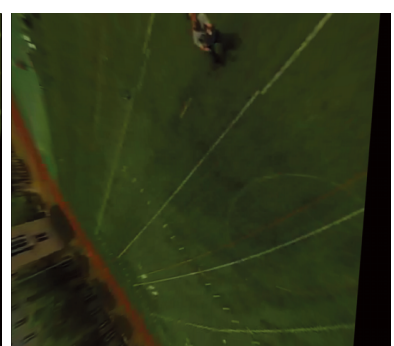

frame $=14$

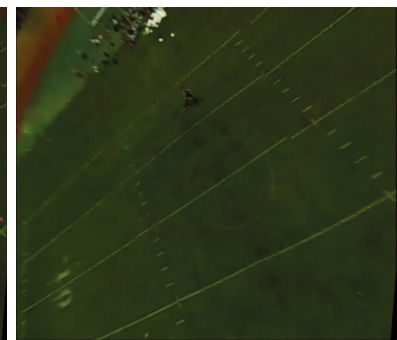

frame $=8$

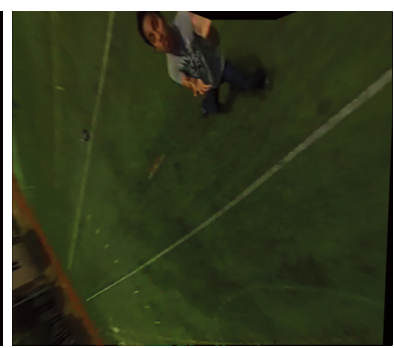

frame $=15$

図 10 ビデオシーケンスからのサンプル映像.

Sample images from the video sequence

同時に，スポーツ観戦の発展に役立つと考えている。

\section{〔文献〕}

1) C. Gramkow. On averaging rotations. Journal of Mathematical Imaging and Vision, 15(1-2):7-16 (2001)

2) R. Hartley and A. Zisserman. Multiple View Geometry in Computer Vision. Cambridge University Press, second edition (2004)

3) T. Kanade, P. Rander, and P. Narayanan. Virtualized reality: Constructing virtual worlds from real scenes. IEEE Multimedia, 4:34-47 (1997)

4) K. Kitani, K. Horita, and H. Koike. Ballcam!: dynamic view synthesis from spinning cameras. In Adjunct proceedings of the 25th annual ACM symposium on User interface software and technology, pp.87-88 (2012)

5) T. Kuwa, Y. Watanabe, T. Komuro, and M. Ishikawa. Wide range image sensing using a thrown-up camera. In Multimedia and Expo (ICME), 2010 IEEE International Conference on, pp. $878-883(2010)$

6) A. Levin, A. Zomet, S. Peleg, and Y. Weiss. Seamless image stitching in the gradient domain. In In Proceedings of the European Conference on Computer Vision (2006)

7) H. Mori, D. Sekiguchi, S. Kuwashima, M. Inami, and F. Matsuno. Motionsphere. In ACM SIGGRAPH 2005 Emerging technologies, p.15 (2005)

8) M.Uyttendaele, A.Eden, and R.Skeliski. Computer vision and pattern recognition. In Eliminating ghosting and exposure artifacts in image mosaics, (2001)

9) T. Ozawa, K. M. Kitani, and H. Koike. Human-centric panoramic imaging stitching. In Proceedings of the 3rd Augmented Human International Conference, pp. 20 (2012)

10) J. Pfeil, K. Hildebrand, C. Gremzow, B. Bickel, and M. Alexa. Throwable panoramic ball camera. In SIGGRAPH Asia 2011 Emerging Technologies, p. 4 (2011)

11) Z. Zhang. Flexible camera calibration by viewing a plane from unknown orientations. In Computer Vision, 1999. The Proceedings of the Seventh IEEE International Conference on, volume 1, pp. 666-673 (1999)

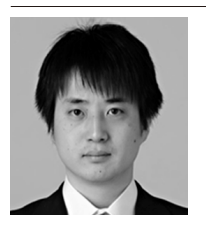

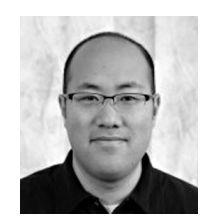

喜谷どリすズ真実 2008 年, 東京大学大学院情報 理工学系研究科博士課程修了. 電気通信大学助教を経て, 2011 年, Carnegie Mellon University, Robotics Institute. 現在 System Scientist. コンピュータビジョ ンに関する研究に従事. 2008 年, MIRU 論文賞. 2010 年, 電子情報通信学会論文賞. 2012 年, ECCV 論文賞. 传衤术秀喜

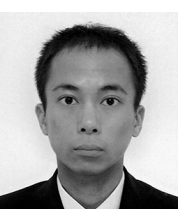

学学部物理学科卒。 2004 年, 同大大学院理学系研究科物理学専攻修士課程修 了. 2006 年, 株式会社ニコン入社. 3 次元復元を中心と したコンピュータビジョンに関する研究開発に従事。

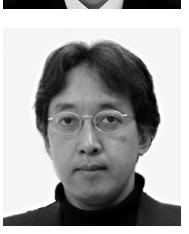

小池莐英樹 1991 年, 東京大学大学院工学系研究科 博士課程修了. 工学博士. 電気通信大学助手, 助教授, 教 授を経て, 2014 年より東京工業大学教授。この間，UC Berkeley 客員研究員. Sydney 大学客員研究員. 20022005 年, 内閣事務官併任. HCI の研究に従事. 特にコン ピュータビジョンを利用した対話型システム, 大規模デー 夕の視覚化等に興味を持つ. 1991 年，JSSST 高橋奨励 賞, 2001 年, IEEE-VR Honorable Mention, 2008 年, VR 学会論文賞, 2013 年, Laval Virtual Grad Prix Award 等. 